\title{
Exchange New Product News
}

Journal of Derivatives \& Hedge Funds (2008) 13, 321-327. doi:10.1057/palgrave.jdhf.1850084

\section{TWO NEW ISHARES ETFS LAUNCHED IN THE XTF SEGMENT ON XETRA}

Deutsche Börse has further expanded its XTF segment for listed index funds on the electronic trading platform Xetra, with two more exchange-traded funds (ETFs) issued by Barclays Global Investors (BGI) now tradable in XTF.

The iShares MSCI Europe (ISIN: DE000A0M5X28) allows investors to participate in the performance of the market-wide MSCI Europe Index. The fund tracks 85 per cent of the total market capitalisation in Europe and comprises equities from 16 countries.

Management fee is 0.35 per cent/year.

The iShares S\&P Global Clean Energy (ISIN: DE000A0M5X10) tracks the performance of the S\&P Global Clean Energy Index. The index currently comprises 30 companies from the clean energy production, clean energy technology and clean energy equipment sectors. The management fee stands at 0.65 per cent per year.

\section{GREATER CHINA PRECISION COMPONENTS LTD FLOATED ON FRANKFURT STOCK EXCHANGE}

Journal of Derivatives \& Hedge Funds, Vol. 13 No. 4, 2008, pp. 321-327 (C) 2008 Palgrave Macmillan Ltd $1753-9641 \$ 30.00$
The IPO of Greater China Precision

Components Ltd. became the first IPO of a Chinese company on Deutsche Börse's Entry Standard.
The Greater China Precision Components Ltd. (ISIN: SG9999005052) was quoted at $€ 3.10$ in its stock exchange debut. The issue price stood at $€ 3.80$, while the placement volume in shares totalled 8.25 million. The lead manager and designated sponsor is VEM Aktienbank AG, while the lead broker is mwb Wertpapierhandelsbank AG.

According to the company's own sources, China Precision Components Ltd develops and produces a wide range of cell phone casings and components, with 1,240 employees. It provides its customers, most of which operate globally, with integrated solutions from design through to production.

Greater China Precision Components is the first Chinese company to go public on Deutsche Börse's Entry Standard. Several other Chinese companies went public in 2007: two on the Prime Standard — ZhongDe Waste Technologies AG and Asian Bamboo AG and four on the Open Market - Gongyou Machines, Sino International Logistic Co., UFC Holding and Classic Dream Properties Ltd.

Greater China Precision Components' listing on the Entry Standard shows how attractive the Entry Standard is for international companies. In terms of market access costs and subsequent costs in further capital increases, as well as liquidity, the Entry Standard offers the lowest capital costs by far in a global comparison. 
This is the conclusion also reached by a current study presented by Professors Christoph Kaserer (Technical University, Munich) and Dirk Schiereck (European Business School), which was published in late 2007. In a comparison of Deutsche Börse's Entry Standard with the alternative markets of Euronext (Alternext), the Hong Kong Stock Exchange (GEM), the London Stock Exchange (AIM), on the Nasdaq and the New York Stock Exchange, the study confirms that the Entry Standard plays an outstanding role in raising capital for smaller and medium-sized companies.

\section{THREE FRENCH CLIENTS CHOOSE AVOX MIFID CLASSIFICATION SERVICE}

Avox, the leading network of financial services providers collaborating for the verification of counterparty data, has been chosen by three French clients Calyon, CM CIC Securities and Société Général Corporate and Investment Banking for Avox's Markets in Financial Instruments Directive (MiFID) Classification Service. In order to meet MiFID requirements, Avox will provide banks with a fully auditable set of data fields for their client records.

With Avox's MiFID service, all three clients have now finished their MiFID client classification process. All of them have been using the Avox service to support their internal teams and a fast rigorous update of their records. All of the clients have chosen Avox following a competitive process to select their service provider. A number of Avox clients are already using the MiFID service.

MiFID will introduce a single market and regulatory regime for investment services and is designed to create a transparent environment for all market participants. With its new service,
Avox researches key performance indicators required by MiFID, for example, total assets, net annual turnover and capital which are necessary to prove the appropriate client classification has been assigned to each entity. Avox also allocates a unique ID, known as the Avid, to every business entity.

The MiFID service incorporates data from authoritative sources. In addition to using electronic registries of this content, Avox dispatches analysis to sources such as court houses and tax offices when the content is available only in hard copy and must be physically scanned on site.

\section{PER CENT RISE IN TURNOVER ON XETRA IN OCTOBER 2007: TOTAL VOLUME OF $€ 239$ BILLION TRADED ON ALL STOCK EXCHANGES IN GERMANY}

In October 2007, €217 billion were turned over on Xetra and on the floor of Börse Frankfurt a rise of 52 per cent year-on-year (October 2006: €142 billion). Thereof $€ 204$ billion were traded on Xetra gaining 55 per cent yearon-year (October 2006: €131.2 billion) and $€ 13$ billion on the floor (October 2006: €11.4 billion). German equities accounted for $€ 203$ billion, foreign equities comprising $€ 10$ billion. More than 97 per cent of the transaction volume with German equities was executed at Börse Frankfurt. More than 79 per cent of foreign equities were traded on Xetra and on the floor.

In the entire month 16 million transactions were executed on Xetra, a rise of 74 per cent year-on-year (October 2006: 9.2 million). According to the Xetra liquidity measure (XLM), Allianz SE was the most liquid DAX ${ }^{\circledR}$ blue chip in October with 4 basis points (bp) for an order volume of $€ 100,000$. EADS N.V. was 
the most liquid MDAX ${ }^{\circledR}$ stock with 20 bp. The most liquid ETF was the db-x-trackers II iBOXX Sovereigns Eurozone 1-3 TR with 2 bp. The most liquid foreign stock was ABN Amro with 7 bp. XLM measures liquidity in electronic securities trading on the basis of the implicit transaction costs. It is expressed in basis points ( $1 \mathrm{bp}=0.01$ per cent); a low XLM denotes high liquidity in a security.

Daimler AG was the strongest DAX ${ }^{\mathbb{R}}$ stock on Xetra in October at $€ 14$ billion. Klöckner \& Co. was the top MDAX ${ }^{\circledR}$ stock at $€ 1.1$ billion while Air Berlin AG led the SDAX ${ }^{\circledR}$ stock at $€ 220.8$ million and Conergy AG headed the TecDAX $^{\circledR}$ at $€ 1.3$ billion. At $€ 2.9$ billion, the iShares DAX EX was once again the exchangetraded fund with the largest turnover.

On all stock exchanges in Germany $€ 239.1$ billion were traded in October according to orderbook turnover statistics - a rise of 51 per cent compared year-on-year (October 2006: $€ 157.7$ billion). This total included $€ 229.5$ billion in equities, warrants and exchange-traded funds, as well as $€ 9.6$ billion in fixed-income securities.

\section{TRADING VOLUMES AT EUREX UP BY 22 PER CENT TO 146 MILLION CONTRACTS: FIXED INCOME DERIVATIVES STRONGEST SEGMENT WITH 61 MILLION CONTRACTS/EQUITY INDEX DERIVATIVES SEGMENT WITH STRONGEST GROWTH YEAR-ON-YEAR}

A total of 146 million contracts were traded on the Eurex international derivatives exchange in October 2007, a year-on-year increase of 22 per cent (October 2006: 119 million contracts). Approximately 1.61 billion contracts were traded year-to-date, surpassing last year's overall volume of 1.527 billion contracts. Open Interest remained stable and reached 133 million contracts at the end of October 2007.

Strongest growth was seen in the equity index derivatives segment, which rose by 52 per cent to 58.4 million contracts (October 2006: 38.3 million contracts). The Dow Jones Euro STOXX $50^{\circledR}$ Index future saw around 24 million contracts, an increase of 54 per cent (October 2006: 15.4 million contracts); turnover of the option increased even more by 66 per cent achieving 22 million contracts.

The equity derivatives segment (equity options and single stock futures) recorded 26.6 million contracts (October 2006: 23.7 million), a growth of 12 per cent year-on-year. Growth drivers were predominantly single stock futures, which increased significantly over October 2006 with 157 per cent. Around 24.4 million contracts were traded in equity options.

The fixed income derivatives segment was the largest in terms of turnover in October with approximately 61 million contracts (October 2006: 57.4 million), an increase of six per cent year-on-year. The strongest traded single derivative was once again the Euro Bund Future with more than 26 million contracts, followed by the Euro Schatz Future with 14.4 million contracts.

Eurex Repo, which operates CHF- and EUR repo markets, set a new daily record in its money market segment Euro GC Pooling in October 2007 , with daily outstanding volume of $€ 24.1$ billion on 24 October. Average outstanding volume reached $€ 16.8$ billion in October 2007, a plus of 21 per cent year-on-year (October 2006: €13.9 billion). All Eurex Repo markets recorded in difficult market conditions in October an average outstanding volume of $€ 85$ billion (October 2006: €88.9 billion). 
Approximately $€ 11.5$ billion (single counting) was traded in October on the Eurex Bonds electronic trading platform, which rounds out Eurex's range of fixed income product range, compared to $€ 13$ billion in October 2006. Trading volume in September 2007 was $€ 11.3$ billion.

\section{TWO NEW LYXOR ETFS LAUNCHED IN THE XTF SEGMENT ON XETRA}

Deutsche Börse has further expanded its XTF segment for listed index funds on the electronic trading platform Xetra, with two more exchange-traded funds (ETFs) issued by Lyxor Asset Management tradable in XTF.

The Lyxor ETF EUROMTS $15+$ Y (ISIN: FR0010481093) enables investors to participate in the performance of a current total of 38 government bonds from euro-zone countries with a residual maturity of more than 15 years. A maximum of two securities per issuer are included in the underlying index.

The Lyxor ETF EUROMTS Covered Bond Aggregate (ISIN: FR0010481127) tracks the performance of 100 covered bonds (Pfandbriefe) from euro-zone issuers, each of which has a residual maturity of at least one year and an AAA-rating. The annual management fee amounts to 0.165 per cent in each case.

\section{EUREX LAUNCHES EURO INFLATION FUTURES}

The international derivatives exchange Eurex launched new Euro inflation futures on 21st January, 2008. The futures contract will be based on the HICP, which measures inflation in the Euro zone. With this product, Eurex is adding a new asset class to its product suite. Exchange traded inflation futures complement the existing markets of inflation linked cash products and OTC derivatives, which have seen rapidly growing volumes. Eurex is the first European derivatives exchange to offer inflation futures.

Inflation futures will be traded on Eurex for the first time with a specific market model to accommodate the fact that inflation and inflation expectations are subject to minor changes during the day: Liquidity will be concentrated in two daily auctions of 15 minutes - opening and closing - where market makers will provide liquidity. During continuous trading market makers will quote upon request.

The growth of the European inflation markets boosted the demand from market participants for efficient and low-cost hedging instruments (derivatives) for managing short-term inflation risks. The new Eurex inflation futures also help the market to calculate prices for derivatives on forward inflation-linked bonds that in a next step can be used to build up an inflation-linked bond options market.

The new futures contract will be based on the unrevised Harmonized Index of Consumer Prices of the Euro zone excluding tobacco (HICP). It is an important measure of consumer price inflation in the Euro zone and serves as a guide for monetary policy. The HICP is calculated monthly by the Statistical Office of the European Communities ('Eurostat').

Inflation-linked instruments have already been available on Eurex Bonds since March 2006. The electronic trading platform (www.eurexbonds.com) - operated by Eurex in cooperation with leading international trading firms - offers inflation-linked government bonds of France, Greece, Italy and Germany. The latter has already generated turnover of almost $€ 10$ billion (single counted) since introduction. 


\section{DEUTSCHE BÖRSE LOOKS BACK ON TWO YEARS OF THE ENTRY STANDARD: 109 COMPANIES CURRENTLY LISTED IN THE SEGMENT}

In late 2007, Deutsche Börse looked back on two positive years of the Entry Standard segment for small and medium-sized companies. Based on current market capitalisation of around $€ 9.5$ billion, the Entry Standard is the largest alternative capital market in continental Europe. The average market capitalisation per company stands at around $€ 88$ million.

As of late 2007, 109 companies were listed on the Entry Standard, including eight companies from Switzerland, Luxembourg, Italy and Canada. Small and medium-sized companies, in particular, consider and value the Entry Standard as a flexible and straightforward form of access to the capital market because of its lower transparency requirements and lower costs. Five companies have already used the segment as a cost-effective means of gaining an initial foothold on the stock exchange, before moving to the more highly regulated General Standard or Prime Standard. Twenty-four companies have used the Entry Standard as a means of further development and moved over from the Open Market. Meanwhile, 24 banks support Entry Standard companies on the stock exchange and monitor the transparency requirements.

Since the Entry Standard was launched, the trend towards market access with prospectus preparation has continued: around 80 per cent of new entrants to the Entry Standard have chosen a public offering and thus an EU issuing prospectus.

The Entry Standard is open to all sectors, with companies primarily coming from the financial services (25), technology (12) and real estate (10) industries. Entry Standard companies are of particular interest to qualified investors; on average, over 86 per cent of the issue volume has been placed with institutional investors that have specialised in small and medium-sized companies, in particular.

\section{DEUTSCHE BÖRSE LAUNCHES THREE AUSTRIA INDICES: DAXGLOBAL AUSTRIA INDICES TRACK AUSTRIAN MARKET}

Deutsche Börse has expanded its DAXglobal index family to include three country indices for Austria. The DAXglobal ${ }^{\circledR}$ Austria Dividend Index tracks Austrian companies with the highest dividend yield. The DAXglobal ${ }^{\circledR}$ Austria Mid-Cap index includes the largest and most liquid mid-cap companies from Austria. The DAXglobal ${ }^{\circledR}$ Austria Eastern Europe Exposure Index allows investors to participate in Austrian blue chips and mid-cap companies that generate part of their revenues in eastern Europe.

The DAXglobal ${ }^{\circledR}$ Austria Dividend Index pursues a dividend strategy based on Austria's 30 largest stocks in terms of market capitalisation. The index contains ten companies with the highest dividend yield. The composition of the index is adjusted annually based on current dividend payments. The weighting of individual stocks in the index is capped at 10 per cent.

The DAXglobal ${ }^{\circledR}$ Austria Mid-Cap Index currently contains the 13 largest companies among Austria's blue chip stocks. These companies must have a market capitalisation of between $€ 100$ million and $€ 1$ billion and a daily trading volume of at least $€ 750,000$. The index covers all sectors, but primarily includes stocks 
from the finance, industry and consumer goods sectors.

The DAXglobal ${ }^{\mathbb{R}}$ Austria Eastern Europe Exposure Index tracks the performance of Austrian companies that generate at least 20 per cent of their revenues from exports to eastern Europe. These countries are: Bulgaria, Romania, Latvia, Estonia, Lithuania, Hungary, Slovakia, the Czech Republic and Slovenia. The index currently comprises 12 companies.

As with all Deutsche Börse indices, the DAXglobal Austria indices are strictly rulebased, transparent and liquid. The composition of all three indices is reviewed on an annual basis in September. Weightings are chained every quarter.

\section{BUNDESBANK AND CLEARSTREAM LAUNCH A SELF-COLLATERALISATION SERVICE}

On 29th October, 2007, the Bundesbank and Clearstream Banking AG, Frankfurt (CBF) launched a self-collateralisation service for the German domestic financial market, which has been developed in close collaboration with market participants. The self-collateralisation service allows credit institutions to use additional central bank liquidity for the settlement of securities transactions without having to reserve central bank cash balances in advance. To do this, the Bundesbank will grant intraday credit against collateral as part of CBF night-time processing. Participants will be able to use the selfcollateralisation service to optimise the management of their central bank liquidity for the CBF night-time processing and make up for any liquidity defaults by counterparties. The new service is based on existing $\mathrm{CBF}$ processing methods and can be used by customers without functional adjustments.

The service will be available to credit institutions which are both CBF customers and monetary policy counterparties of the Bundesbank or which are counterparties that act as a correspondent bank for CBF customers in the cash settlement of securities trading business.

The Bundesbank and Clearstream have posted further information on the self-collateralisation service on the Bundesbank's website at www.self-collateralisation.de, from which participants can also download all of the application forms needed to register for the self-collateralisation service.

\section{CLEARSTREAM OPENS LINK TO SLOVENIA}

Clearstream, the international central securities depository (ICSD) within the Deutsche Börse Group, began offering settlement service for Slovenian Government securities as of 29th October, 2007. With this addition, Clearstream's network now reaches 45 domestic markets around the globe: 31 in Europe, 5 in the Americas and 9 in the Asia Pacific region, South Africa, Australia and New Zealand. It is the widest network of any ICSD and enables counterparties in local markets to efficiently settle eligible securities through Clearstream's operational hub in Luxembourg.

Customers are able to settle transactions on Clearstream's Creation platform both on a 'Free of Payment' (FoP) and against payment (DvP) basis via the account that Clearstream Banking has opened with KDD. Nova Lubljanska Banka, the biggest Slovenian bank, has been named Clearstream's account operator. Initially Bridge transactions are excluded because Slovenian 
securities will not be Bridge eligible at the start of the new service.

The new link gives Clearstream's customers the opportunity to enter the Slovenian market, a country of two million people, which was the first of the ten states that entered the European Union in May 2004 to join the eurozone, in 2007, as the 13th member of the currency union. The development of this new link demonstrates Clearstream's commitment to facilitate market openness and to create solutions in response to customer and market needs.

\section{S\&P FUND SERVICES: S\&P-RATED FUNDS-OF-HEDGE-FUNDS MAKE MONEY IN DIFFICULT TIMES}

Funds-of-hedge-funds rated by Standard \& Poor's Fund Services made money in the third quarter despite concern in the markets over the ongoing credit crunch.

Research just published by the leading provider of qualitative fund management ratings, available at www.funds.standardandpoors.com, shows that in aggregate the S\&P rated fundsof-hedge-funds returned around 1 per cent, outpacing hedge funds which lost an estimated 1-1.5 per cent.

S\&P-rated funds-of-hedge-funds also showed net new inflows exceeding redemptions during the third quarter. A side effect of the turmoil in the financial markets has been increased insistence on transparency from many fundsof-hedge-funds. Looking ahead, S\&P rated funds-of-hedge-fund managers are fairly unanimous in their enthusiasm for emerging markets and Asia. 